\title{
Oil sands tailings dewatering — can it be done?
}

\author{
S. Longo Golder Paste Technology Ltd., Canada \\ R. Francoeur Golder Paste Technology Ltd., Canada \\ M. Labelle Golder Paste Technology Ltd., Canada \\ I. Wislesky Golder Associates Ltd., Canada
}

\begin{abstract}
With the advent of Energy Resources Conservation Board of Alberta (ERCB) Directive 074, there has been increased pressure on oil sands operators to find practical, field proven solutions to deal with tailings management. While significant research and development has gone into understanding the characteristics of oil sands tailings materials and their subsequent behaviours in the field, there are still uncertainties. All operations will need to dewater their oil sands tailings in some manner to produce a material that will gain strength over time. There is great interest among oil sands companies to investigate and potentially apply different dewatering techniques for surface disposal of their waste materials.
\end{abstract}

This paper presents the highlights of lab and field testing programs that have focused on thickening the multiple tailings streams that are produced by oil sands operators. Each tailings stream has its challenges and these will be discussed in the context of various dewatering methods that have been trialled. In addition, some focus will be put on how to employ these dewatering methodologies to compliment deposition strategies.

\section{The setting}

The tailings 'problem' in the oil sands industry in Alberta is the world's worst kept secret. Since the beginning of oil sands mining in the 1960s huge volumes of tailings have been produced and are continuing to be produced. These tailings and associated effluent (fluid fine tailings) must be contained and cannot be released directly to the environment. The tailings are composed of very fine particles that are piped out, generally as a slurry, to containment areas. As a result, vast surface areas are currently occupied with fine, saturated tailings and effluent. The tailings in these ponds settle and consolidate very slowly. The accumulation of fluid fine tailings is commonly referred to as mature fine tailings (MFT).

The accumulated volume and aerial expanse of these fluid fine tailings and the potential associated environmental concerns have received more and more public attention to the point where governments, public groups and aboriginal communities have voiced their concerns.

While millions of dollars have been spent in research and development and multiple tailings management techniques and field trials have been attempted to solve the problem, as of 2010 there is still no practical field proven solution to deal with the legacy volume and the huge tonnage produced on a daily basis. With more applications to mine pending and no permanent solution available to oil sands operators, pressure from government and the public forced the ERCB to institute some rules regarding tailings management.

\section{$2 \quad$ Why dewater?}

\subsection{Directive 074}

The ERCB issued Directive 074 in February 2009. This directive presents specific performance criteria and requirements for oil sands mining schemes with respect to tailings management and includes phasing in the requirements over a three year period. The main thrust of the Directive is to reduce the huge volume of accumulated fluid fine tailings and their associated water management and environmental issues. The Directive focuses on management and accountability of tailings and associated process water/effluent. 
Dedicated disposal areas (DDAs) are required to capture $50 \%$ by weight of the fines (defined as $<44 \mu \mathrm{m}$ ) in the oil sands processed (or an equivalent amount from accumulated MFT. The 50\% fines capture requirement is in addition to the hydraulically placed fines captured currently in hydraulically placed dykes and beaches.

DDAs must be formed in a manner that ensures trafficable deposits. The performance criteria are based on the strength of the deposit. In order to allow for auditing, the ERCB set the following criteria to be achieved annually:

- Minimum undrained shear strength of 5 kilopascals $(\mathrm{kPa})$ for the material deposited in the previous year.

- Removal or remediation of material deposited in the previous year that does not meet the $5 \mathrm{kPa}$ requirement.

- Deposit ready for reclamation within five years after active deposition has ceased. The deposit will have the strength, stability, and structure necessary to establish a trafficable surface. The surface must have minimum undrained shear strength of $10 \mathrm{kPa}$.

- Reports are to be prepared annually detailing the tailings management process and the deposition results with respect to the Directive and agreed upon schedule and methodology.

In effect, the Directive indicates that both existing and newly formed tailings will need to be formed into dry land deposits. For this to occur, an effective means of separating the effluent/liquid from the tailings solids must be employed. Some form of dewatering will be required (Houlihan et al., 2010).

\subsection{Sustainability}

In this day and age, the overall goal with any mining project is to be a sustainable development with the intent for reclamation and closure in as progressive a manner as possible. As a part of Directive 074 it should be noted that the current regulation reduces the rate of MFT growth and at some point in the future it is anticipated that zero growth MFT and reduction in accumulated MFT will be required. This is a fundamental shift in the current operation of oil sands mines and process plants that will require a fundamental shift in operating philosophy. Unlike normal mining operations which are very linear in thought and operation, the idea of tailings or waste management needs to begin at the end. What is meant by this is that once the end result is established, i.e. what the deposit should look like upon closure, one can then work backwards to produce a material to meet those requirements and characteristics. Only by engineering your waste, so to speak, will the end results be achievable.

There are multiple factors to take into account when facing these kinds of long term issues which include:

- material characteristics and behaviour

- $\quad$ storage capacity

- stability of stack (geotechnically and geochemically)

- water management (collection, treatment, reuse and release)

- seepage/leachate

- operational requirements

- life of mine

- closure and reclamation systems

- capital and operating costs.

As mentioned above, the driver has to be the deposition strategy and the process technology to achieve this will follow. There is no one size fits all and in order to reduce or eliminate the production of MFT, tailings management and, in particular, deposition planning needs to become a major area of focus for oil sands 
operators. The entire system must be looked at from mining, through processing, dewatering, transport, distribution, water treatment and recycling, reclamation and closure.

\section{Dewatering technologies}

\subsection{General dewatering technologies and associated deposition strategies}

Although an operator may be able to accomplish the Directive requirements with one technology, the ERCB has recommended the use of a suite of technologies to mitigate implementation risk factors and increase operational flexibility. The choice of process technology, of course, must be done in conjunction with the depositional strategy; otherwise, the risk is that the process will not be able to achieve the requirements of the deposition plan. The advantages of one methodology over another is dependent on many factors, including production rate, process type, chemistry, physical properties, location, distance from mill to disposal area, water management needs, operational constraints, cost, etc.

The following are the dewatering strategies that are being explored prior to deposition:

- thickening (conventional and paste)

- in-line flocculation

- centrifuge

- co-mingling

- other strategies such as electro-osmosis may be explored further in the future.

\subsubsection{Thickening}

Thickening generally involves a large thickener tank with a slow turning rake system into which the tailings slurry is placed after the extraction process, along with a flocculant. The raking process, geometry of the tank and rake system, retention time and flocculant along with the basic material properties controls the potential thickness of the product. The thickened material is extracted from the bottom of the tank and clarified water/effluent is decanted from the top of the tank.

The thickened material is pumped to a containment facility (or pit or back underground) and the decanted effluent can be reused directly in the extraction process or placed in a temporary separate facility for later reuse or treatment and release. Paste can be obtained from this process depending on the grain size of the material and may also require some modifications to the tank and the other control measures indicated above.

\subsubsection{In-line flocculation}

This dewatering measure involves placement of a flocculant in the pipeline at a sufficient distance from the discharge point to allow the required mixing/contact to take place in the pipe. The tailings settle out and separate from the effluent upon discharge and deposit forming a beach with the effluent flowing away into a collection pond.

\subsubsection{Centrifuge}

A centrifuge is a device that spins, providing a gravitational force that causes the tailings to form against a porous side wall. The effluent passes through the wall and the solid tailings remains. These tailings are then collected and sent out to a tailings containment facility generally via truck or conveyor.

\subsubsection{Co-mingling}

Co-mingling involves mixing coarser materials with fine materials to produce a product that is more amenable to dewatering and strength gain. In some processes the tailings go through a cyclone process to separate the finer fraction from the sands. These materials can be recombined in specific portions to form a uniform, non-segregating tailings (NST) with better dewatering and consolidation characteristics. Additives that have been considered include waste rock, sand, fly ash, gypsum, $\mathrm{CO}_{2}$, etc. 


\subsection{Deposition strategies}

After applying these various dewatering process technologies, additional dewatering is generally still required and this can be achieved through the deposition strategy selected. The deposition strategies to be considered are:

- thick lift

- thin lift

- cell structure

- $\quad$ single end point discharge

- multiple spigot discharge.

The use of supplementary measures to promote dewatering and consolidation has also been considered and these include toe drains, ditches, deposition slope, underdrains and the effect of freeze-thaw cycles. In all cases it is important that a slope is formed to ensure that water readily drains away from the deposit and is not allowed to form a pond on or adjacent to the deposit.

\subsubsection{Advantages/disadvantages}

\subsubsection{Thick lift}

This would likely be the preferred deposition methodology if appropriate dewatering, consolidation and strength gain could occur. Unfortunately, the low permeability nature of the tailings means dewatering will be slow. It will be necessary to optimise the thickness of the material to ensure sufficient strength gain is occurring throughout. One means to allow for increased layer thickness would be to provide a number of lateral drains, but this would increase the cost and pose some operational difficulties. Co-mingling could also be considered to facilitate this method.

\subsubsection{Thin lift}

Thin lift deposition of thickened tailings can generally be considered to be less than $0.5 \mathrm{~m}$ per lift. A thin lift is placed and given time to consolidate prior to application of a subsequent lift. The thinner the lift, the faster it will dewater. The effective drainage is influenced by the permeability of the new layer and the underlying layer, as well as the moisture content of the underlying layer. Evaporation can also play a major role. This deposition method requires large areas and the ability to move from one area to another to allow sufficient drying time for each layer.

\subsubsection{Cell structure}

Cells can be constructed in advance of deposition with a strong and permeable material (sand sizes to rockfill). These cells could then be filled in and allowed to dewater and consolidate while other cells are filled in. The cells could be filled in with thin lifts or thick lifts depending on the overall behaviour of the tailings. After sufficient strength gain is achieved, new cells can be constructed over top of the previously deposited cells.

\subsubsection{Discharge methods}

Tailings are generally pumped through a pipeline to the tailings disposal area. Depending on the corresponding deposition strategy, either single point discharge or multiple spigot discharge options exist. The advantage with single point discharge is that you can direct the flow in a straightforward way with minimal operational input. With multi point discharge you can direct the flow in a more systematic way to build the deposit without the hassle of repeated pipeline moves and more easily facilitate the uniformity of thin lift layers. In the case of cell structures, multi spigot discharge makes switching between cells more practical. 


\section{$4 \quad$ Test results}

Since 2006, there has been significant work done on a variety of tailings materials from the Alberta oil sands. The following sections will highlight the major findings and some of the performance indicators to date.

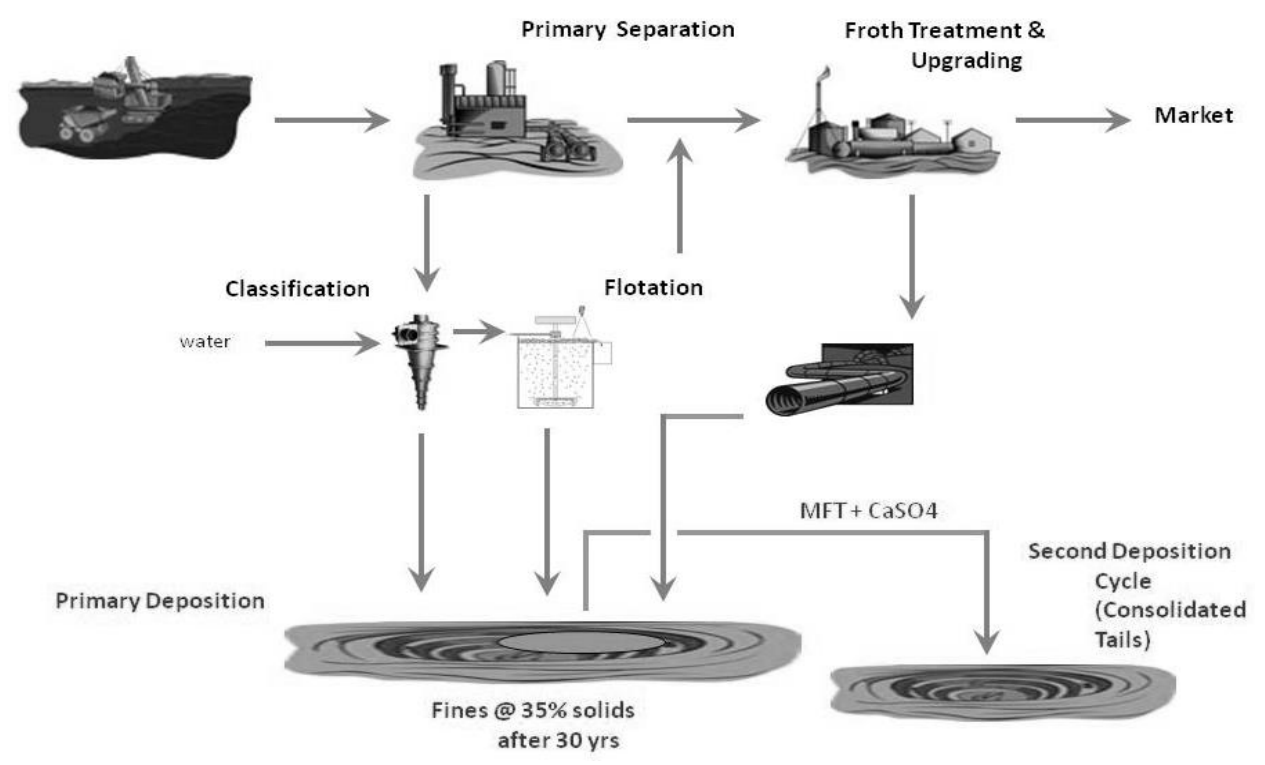

\section{Figure 1 Typical process}

\subsection{Laboratory data}

In the typical flow sheet shown (Figure 1) there are multiple tailings streams coming out of an oil sands production circuit. Each site or operation will have different quantities and mixes of these tailings streams:

- cyclone underflow and overflow tailings

- flotation tailings

- recovery unit froth treatment tailings (additional bitumen extraction process)

- MFT

- consolidated tailings.

As can be seen in Figure 1, there are several tailings streams that come out of an oil sands operation. The cyclone underflow and overflow tailings are from the primary classification system. The flotation tailings are out of the flotation process coming after primary separation and the froth treatment tailings are the waste output of the froth treatment stage of processing. The froth treatment process varies between oil sands operators and they have different terminology for the resulting tailings stream. MFT (or fluid fine tailings) are the result of these four possible tailings streams being deposited in the TMA and the segregation that happens over time. Basically, the coarse fraction is used to build dykes and dams with the fine fraction being deposited in the middle, what happens over time is that, unlike most metal mines with similar deposition strategies, virtually no settling or consolidation happens. The tailings get deposited at $25-30 \mathrm{wt} \%$ and after 30 years they might be at $35 \mathrm{wt} \%$ solids. They tend to gain no strength and they tend to retain water. In fact, they become almost impossible to reclaim in the current state. Many operators have spent time and effort on manipulating this MFT to achieve the consolidation and strength gain required to close and reclaim a facility. One of these options has been consolidated tailings or 'CT'. CT is a process whereby the MFT is taken from the pond mixed with sand and gypsum, or the like, and re-deposited. The purpose is to attempt to change the grain size and promote permeability changes so that strength gain and consolidation can happen. CT and other processes like it are trying to achieve trafficability on the tailings deposit.

Initially, in any bench scale testing program, small quantities of non-thickened tailings are received in the laboratory for testing. The laboratory testing carried out on these samples generally includes: 
- index tests

- primary stream thickening (settling columns and bench scale thickening units; mini-pilot plant testing; underflow) (Figure 2)

- secondary stream thickening or clarification (overflow).

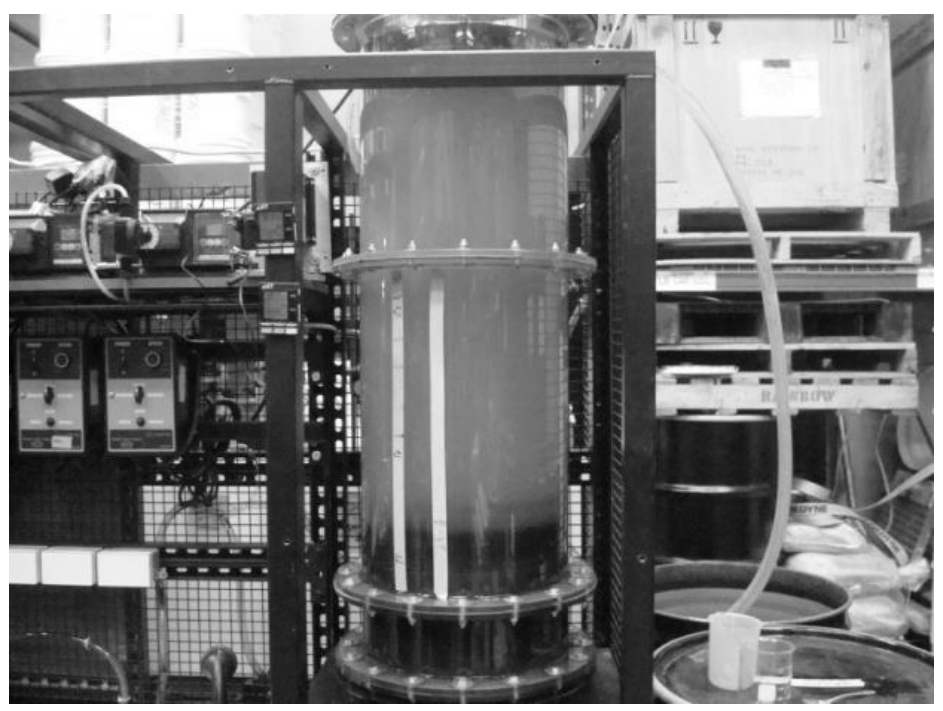

Figure 2 Mini portable thickener plant

Results of testing on three different tailings streams are presented on Tables 1,2 and 3 covering the following test parameters:

- $\quad$ feed wt $\%$ solids

- underflow (U/F) density achieved

- maximum underflow density possible

- $\quad$ overflow $(\mathrm{O} / \mathrm{F})$ quality

- a sample of tailings after laboratory thickening is shown in Figure 3.

Table 1 Summary of test results from froth treatment samples

\begin{tabular}{|c|c|c|c|c|c|c|}
\hline Sample & $\begin{array}{l}\text { Characterisation } \\
\text { Tests }\end{array}$ & $\begin{array}{l}\text { Feed wt\% } \\
\text { Solids }\end{array}$ & $\begin{array}{l}\text { Floc } \\
\text { Dosage } \\
\text { (g/tonne) }\end{array}$ & $\begin{array}{l}\text { U/F } \\
\text { Density } \\
\text { (24 hrs) }\end{array}$ & $\begin{array}{l}\text { Max U/F } \\
\text { Density } \\
\text { (wt\% Solids) }\end{array}$ & $\begin{array}{l}\text { O/F Quality } \\
\text { (wt\% Solids } \\
\text { in O/F) }\end{array}$ \\
\hline Sample \#1 & $\begin{array}{l}58 \% \text { passing } \\
20 \mu ; 1.57 \text { S.G. }\end{array}$ & $\begin{array}{l}5 \% \text { diluted } \\
\text { from } \sim 20 \%\end{array}$ & 300 & $58 \%$ & - & $0.3-0.5 \%$ \\
\hline $\begin{array}{l}\text { Sample \#2 } \\
\text { (single floc) }\end{array}$ & $\begin{array}{l}35 \% \text { passing } \\
20 \mu ; 1.87 \text { S.G. }\end{array}$ & $\begin{array}{l}5 \% \text { diluted } \\
\text { from } 10-15 \%\end{array}$ & 75 & $46 \%$ & 51.7 & $0.4 \%$ \\
\hline
\end{tabular}


Table 2 Summary of test results from flotation tailings samples

\begin{tabular}{lllllll}
\hline Sample & $\begin{array}{l}\text { Characterisation } \\
\text { Tests }\end{array}$ & $\begin{array}{l}\text { Feed wt\% } \\
\text { Solids }\end{array}$ & $\begin{array}{l}\text { Floc } \\
\text { Dosage } \\
\text { (g/tonne) }\end{array}$ & $\begin{array}{l}\text { U/F Density } \\
(\mathbf{2 4} \text { hrs) }\end{array}$ & $\begin{array}{l}\text { Max U/F } \\
\text { Density } \\
\text { (wt\% Solids) }\end{array}$ & $\begin{array}{l}\text { O/F Quality } \\
\text { (wt\% Solids } \\
\text { in O/F)) }\end{array}$ \\
\hline Sample \#1 & $\begin{array}{l}\text { 15\% passing } \\
20 \mu ; 2.68 \text { S.G. }\end{array}$ & $\begin{array}{l}10 \% \text { diluted } \\
\text { from 15\% }\end{array}$ & 100 & $52 \%$ & - & $0.03 \%$ \\
\end{tabular}

Table 3 Summary of test results from MFT samples (from Ahmed et al., 2009)

\begin{tabular}{lllllll}
\hline Sample & $\begin{array}{l}\text { Characterisation } \\
\text { Tests }\end{array}$ & $\begin{array}{l}\text { Feed wt\% } \\
\text { Solids }\end{array}$ & $\begin{array}{l}\text { Floc } \\
\text { Dosage } \\
\text { (g/tonne) }\end{array}$ & $\begin{array}{l}\text { U/F Density } \\
(\mathbf{2 4} \text { hrs) }\end{array}$ & $\begin{array}{l}\text { Max U/F } \\
\text { Density } \\
\text { (wt\% Solids) }\end{array}$ & $\begin{array}{l}\text { O/F Quality } \\
\text { (wt\% Solids } \\
\text { in O/F)) }\end{array}$ \\
\hline Sample \#1 & $\begin{array}{l}\text { 66\% passing } \\
20 \mu ; 2.28 \text { S.G. }\end{array}$ & $\begin{array}{l}3 \% \text { diluted } \\
\text { from 30\% }\end{array}$ & $300-500$ & $46-50 \%$ & - & $0.06-0.08 \%$ \\
$\begin{array}{l}\text { Sample \#2 } \\
\text { (two stage }\end{array}$ & $\begin{array}{l}87 \% \text { passing } \\
\text { floc add'n) }\end{array}$ & $\begin{array}{l}3 \% \text { diluted } \\
\text { from 31\% }\end{array}$ & $\begin{array}{l}250 \text { each } \\
(2 \text { stage } \\
\text { floc) }\end{array}$ & $45 \%$ & 44.9 & $0.4-0.6 \%$ \\
$\begin{array}{l}\text { Sample \#3 } \\
\text { (day 1) }\end{array}$ & $\begin{array}{l}56 \% \text { passing } \\
20 \mu ; 2.08 \text { S.G. }\end{array}$ & $\begin{array}{l}3 \% \text { diluted } \\
\text { from 36\% }\end{array}$ & 500 & - & & \\
$\begin{array}{l}\text { Sample \#3 } \\
\text { (day 2) }\end{array}$ & $\begin{array}{l}56 \% \text { passing } \\
20 \mu ; 2.08 \text { S.G. }\end{array}$ & $\begin{array}{l}3 \% \text { diluted } \\
\text { from 36\% }\end{array}$ & 500 & - & 43.8 & $0.14-0.32$ \\
$\begin{array}{l}\text { Sample \#4 } \\
\text { (day 1) }\end{array}$ & $\begin{array}{l}56 \% \text { passing } \\
20 \mu ; 2.08 \text { S.G. }\end{array}$ & $\begin{array}{l}3 \% \text { diluted } \\
\text { from 35\% }\end{array}$ & 550 & - & 44.2 & $0.35-0.53$ \\
$\begin{array}{l}\text { Sample \#4 } \\
\text { (day 2) }\end{array}$ & $\begin{array}{l}56 \% \text { passing } \\
20 \mu ; 2.08 \text { S.G. }\end{array}$ & $\begin{array}{l}3 \% \text { diluted } \\
\text { from 35\% }\end{array}$ & 585 & - & 41.6 & $0.12-0.31$ \\
\hline
\end{tabular}

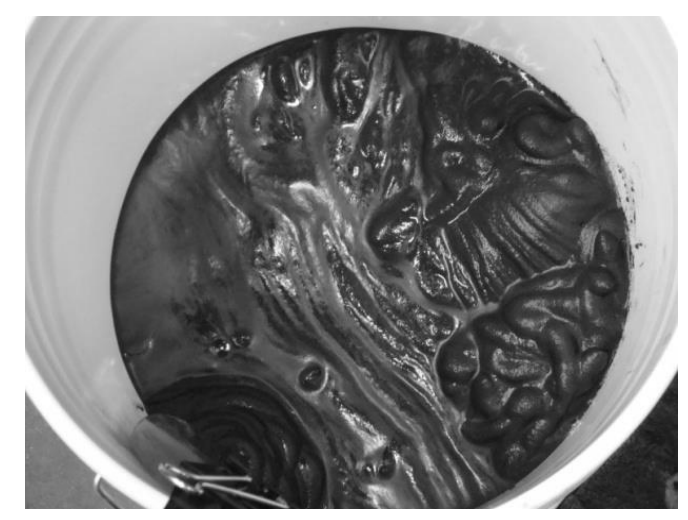

Figure 3 Thickened tailings

The important things to note out of the above results are as follows:

- Generally speaking, the coarser the particle size distribution (PSD) the better the thickening results will be (blended streams are currently being looked at and have provided some promising results).

- Feed density optimisation is critical and the range of MFT feed densities is much lower (3-5\%) than froth treatment feeds (8-10\%) or flotation tailings feed (10-12\%).

- Using a single flocculant underflow density of $44 \mathrm{wt} \%$ can be achieved for the MFT sample. 
- Using a single flocculant, minimal water release was observed from the MFT underflow samples. Two stage flocculation of MFT showed promising results in that it released more water than single stage flocculation in the same time period.

\subsection{Dewatering performance}

The performance in each of the testing formats $(1 \mathrm{~L}, 4 \mathrm{~L}$, bench scale paste thickener and mini-pilot plant) for each of the materials tested showed consistent and increasing performance in terms of underflow density.

Table 4 Summary of dewatering performance through all formats single flocculation

\begin{tabular}{llll}
\hline Type of Testing & $\begin{array}{l}\text { Froth Treatment Tailings } \\
\text { (wt\% Solids) }\end{array}$ & $\begin{array}{l}\text { Flotation Tailings } \\
\text { (wt\% Solids) }\end{array}$ & $\begin{array}{l}\text { MFT } \\
\text { (wt\% Solids) }\end{array}$ \\
\hline 1L & 37 & - & 28 \\
4L & 39 & 52 & 31 \\
Bench-scale thickener & $40-46$ & - & - \\
Mini-plant & $42-47$ & - & 46 \\
Centrifuge & 47.9 & 63 & 56 \\
\hline
\end{tabular}

Table 5 Summary of dewatering performance through all formats two stage flocculation

\begin{tabular}{lll}
\hline Type of Testing & $\begin{array}{l}\text { Froth Treatment Tailings } \\
(\mathbf{w t} \% \text { Solids) }\end{array}$ & $\begin{array}{l}\text { MFT } \\
(\mathbf{w t} \% \text { Solids })\end{array}$ \\
\hline 1L & 39 & 11 \\
4L & $45-46$ & 18 \\
Bench-scale thickener & 46.8 & 45.1 \\
Mini-plant & - & 44.2 \\
Centrifuge & 54.2 & - \\
\hline
\end{tabular}

The increase in underflow density results or 'scale up' between the various settling test procedures tends to depend very heavily on the material type (MFT has much greater increase than the froth treatment tailings) and is indicative of the move from static bench scale testing to dynamic test methods. It is consistent with what would be expected from each stage, although it is substantially different from what would be seen in a similar comparison of base or precious metal tailings.

\subsection{Major effects}

In the course of the testwork the following major effects were noted:

- temperature (room $17^{\circ} \mathrm{C}$ versus elevated process $90^{\circ} \mathrm{C}$ )

- overflow recycling

- underflow recycling

- fines material content.

\subsubsection{Temperature}

In the case of temperature, the highest underflow solids were highly dependent on feed \% solids (at room or elevated temperatures). Also flocculant dosage and type were found to be highly dependent on temperature. There were many flocculants that worked well at room temperature but produced minimal underflow density at elevated temperatures. The switchover point between working and not working flocculants seemed to be at the $40^{\circ} \mathrm{C}$ mark. 


\subsubsection{Overflow recycling}

In the case of overflow recycling, with all materials there was a significant reduction in underflow percent solids (between 17-50\%) with the Froth Treatment sample, and solids content in overflow increased substantially even after the first recycle of overflow and continued to increase over time/number of recycles. Interestingly, the settling velocity increased each time the overflow was recycled. By treating or partially treating the overflow and then recycling, this effect was minimised, if not eliminated.

\subsubsection{Underflow recycling}

In a similar manner, recycling the underflow (which is a common practice in the metals industry) also appears to reduce the overall underflow solids density while increasing the settling velocity. More investigation into this aspect is required to quantify the reduction of the underflow solids density and to determine if there is a practical limit of recycles before it is manifested.

There is a need to investigate the underflow recycling issue in dynamic mode as opposed to static bench scale tests.

\subsubsection{Fines material content}

Generally speaking, the amount of fines present in all samples tends to blind any kind of filtering process limiting the effectiveness of filtration as a standalone dewatering option. However, if cycloning or other fines separation processes are implemented, filtration could be considered an option.

Also, an expected result was the confirmation that any recirculation load of fines or flocculant is problematic for final underflow density.

\subsection{Geotechnical performance}

In general there are four main mechanisms to promote consolidation and desiccation in a stack:

- weight

- evaporation

- drainage

- freeze/thaw.

Methods to enhance these can include acidification ( $\mathrm{CO}_{2}$ addition), reworking (ploughing), other additives, covers, etc.

Producing a non-segregating material is also considered to be a key to performance and site management. If segregation occurs, then one is effectively required to deal with different materials in a single disposal area which adds a level of complication. Fines removal in advance of deposition could be considered within the tolerances of Directive 074 as a means of improving the geotechnical and drainage characteristics of the deposit.

In testing done to date, with respect to the various dewatering and geotechnical techniques discussed earlier, some significant early findings are below:

- Some physical properties of oil sands tailings are not easy to determine.

- Some In-line flocculation tends to inhibit evaporation potential of the deposited tailings.

- Flocculants can be temperature dependent.

- The thickening process is dependent on the tailings production process (rate, water content, temperature, chemistry, etc.).

- The effects of freeze/thaw and evaporation are not readily quantifiable.

- The thickening process must continue after deposition to maintain pumpability. 
- Overall there appears to be a need in the industry to create a set of standardized test procedures to evaluate both tailings materials and additive effectiveness.

- An acceptable lift thickness is dependent on the drainage characteristics of the material, the available area for tailings, the production rate, the surface slope, additional drainage measures in place and the meteorological conditions.

- Effective means are required to maintain a deposit in a drained state and to promote drainage away from the tailings.

\section{$5 \quad$ Practical considerations}

\subsection{What to watch out for}

In the experience gained by the testwork performed over the last few years it is clear that all tailings streams can be dewatered to some extent. The key is to understand the process, chemistry, site conditions, availability of potential additives, quantity, production rate and meteorological conditions. Each site will therefore have a unique solution.

There is no one size fits all to meet the thickening and deposition needs. It is important to note that fines capture, as well as strength requirements, must be in accordance with Directive 074.

\subsection{What to aim for}

There needs to be a concerted effort to develop a set of standard test procedures to understand the behavioural characteristics of oil sands tailings. In addition, the dewatering that takes place after deposition requires more study and quantification. Consideration could also be given to handling some of the fines separately to optimise the thickening process.

It is recommended that a holistic and systematic approach be applied to meeting the conditions presented in Directive 074. This could include, but not be limited to, the following:

- understanding the site conditions (deposition area, location, meteorology, etc.)

- understanding all the process characteristics (quantity, production rate, physical properties, chemical properties, etc.)

- understanding the properties of the tailings based on standardised test methods

- additive screening tests (Figure 4)

- thickening methodology testing

- small scale deposition tests (Figures 5 and 6)

- large scale deposition tests (Figure 7)

- field deposition tests/trials

- modelling

- implementation

- instrumentation and monitoring. 


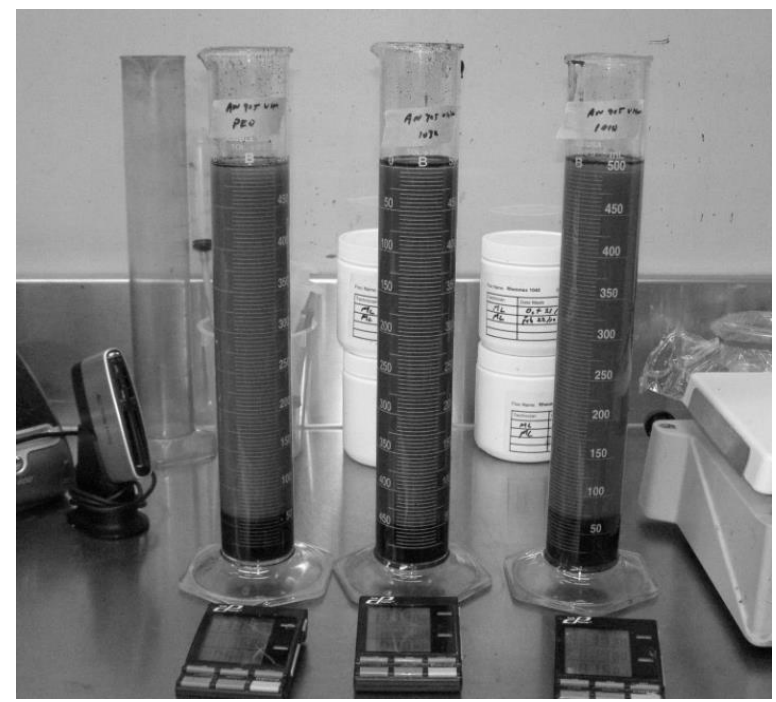

Figure 4 Flocculant screening tests

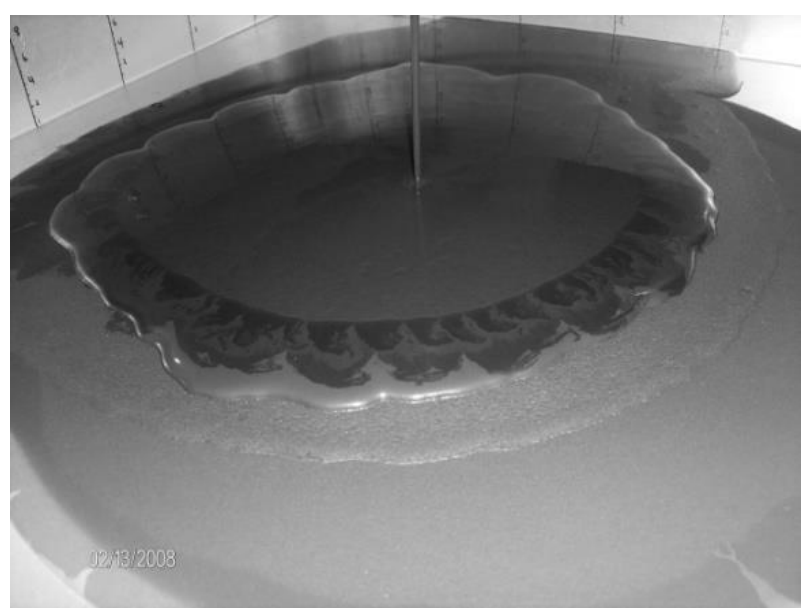

Figure 5 Small scale deposition test

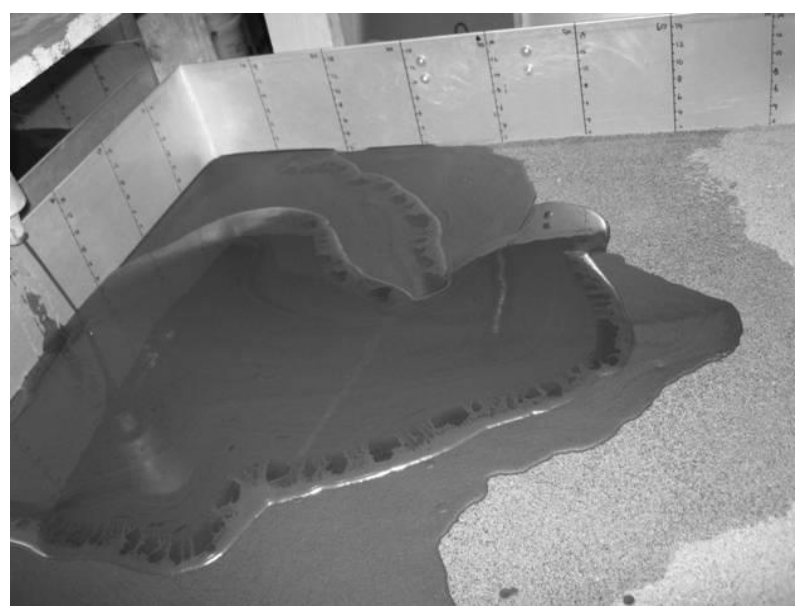

Figure 6 Small scale deposition tests with sand bottom 


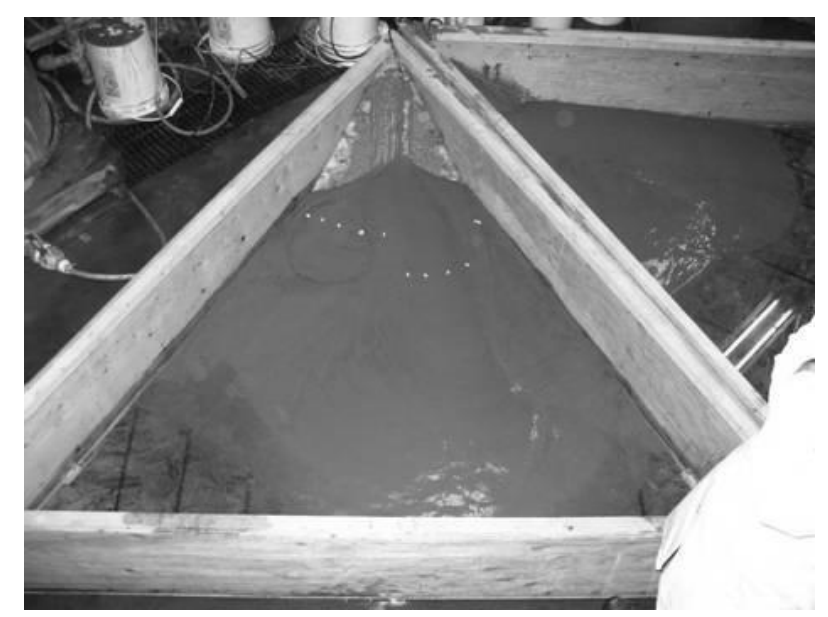

Figure 7 Larger scale deposition test (modified flume)

There are potentially other dewatering methods that could be explored and an open mind is necessary to develop these technologies that may prove to be better at a given site. Electro-kinetics is one thickening method that has merit for consideration. There are also many additives that may be appropriate at one site over another such as polymers and local waste or overburden materials.

\section{References}

Ahmed, M., Labelle, M., Brown, R. and Lahaie, R. (2009) Paste Pumping and Deposition Field Trials and Concepts on Syncrude's Dewatered MFT (Centrifuge Cake), in Proceedings Thirteenth International Conference on Tailings and Mine Waste (Tailings and Mine Waste '09), University of Alberta Geotechnical Centre, 1-4 November 2009, Banff, Alberta, Canada, pp. 417-427.

Houlihan, R.H., Mian, M.H. and Lord, E.R. (2010) Oil Sands Tailings - Technology Developments and Regulation, in Proceedings 13th International Seminar on Paste and Thickened Tailings (Paste2010), R.J. Jewell and A.B. Fourie (eds), 3-6 May 2010, Toronto, Canada, Australian Centre for Geomechanics, Perth, pp. 423-435. 